\title{
Mesocosm study of particle dynamics and control of particle-associated bacteria by flagellate grazing
}

\author{
Kam W. Tang ${ }^{1, *}$, Hans-Peter Grossart ${ }^{2}$, Emily M. Yam ${ }^{1}$, George A. Jackson ${ }^{3}$, \\ Hugh W. Ducklow ${ }^{1}$, Thomas Kiørboe ${ }^{4}$ \\ ${ }^{1}$ Virginia Institute of Marine Science, 1208 Greate Road, Gloucester Point, Virginia 23062, USA \\ ${ }^{2}$ IGB-Neuglobsow, Alte Fischerhuette 2, Stechlin, 16775, Germany \\ ${ }^{3}$ Department of Oceanography, Texas A\&M University, College Station, Texas 77843, USA \\ ${ }^{4}$ Danish Institute for Fisheries Research, Kavalergården 6, Charlottenlund, 2920, Denmark
}

\begin{abstract}
The goal of this study was to attain an integrated understanding of the dynamics of attached microbial communities in nature as governed by the component processes of particle formation, colonization, detachment, growth and interspecific interactions among the microbes. The study was conducted in mesocosms in a Danish fjord over a 2 wk period in April to May 2005. Despite nutrient additions, chlorophyll and particle concentrations were low and no distinct phytoplankton blooms were observed. Particle volume concentration was dominated by particles $>100 \mu \mathrm{m}$. The abundance of attached bacteria was weakly but positively correlated with total particle volume. Phylogenetic composition of attached bacteria became increasingly different from that of free bacteria through time. Growth rates of free and attached bacteria were 0.31 and $0.023 \mathrm{~d}^{-1}$, respectively. Colonization experiments with model agar aggregates showed that the bacterial community had limited apparent diffusivity but strong chemotaxis, which resulted in an up to 8-fold increase in bacterial colonization rates with organic-enriched aggregates. Estimated residence time of attached bacteria on aggregates was 21 min or less. Grazing mortality derived from temporal changes in attached bacterial abundance in the presence or absence of grazing activities ranged from 0 to $9.8 \mathrm{~d}^{-1}$. In comparison, grazing mortality of free bacteria was 0.06 to $0.91 \mathrm{~d}^{-1}$, suggesting that the bacterivorous flagellates were more adapted to grazing on surfaces than in free suspension. Very few attached flagellates were observed in the experiments, and microscopic observations revealed that many flagellates were attached only temporarily to surfaces. Our study showed that grazing mortality is a critical but often underappreciated factor in regulating marine snow bacterial population abundance. The loose association of bacterivorous flagellates with aggregates requires that their role be evaluated by direct grazing measurements instead of simple quantification of attached flagellate abundance.
\end{abstract}

KEY WORDS: Marine snow · Aggregation · Colonization · Grazing mortality · Bacteria · Flagellates · Chemotaxis

Resale or republication not permitted without written consent of the publisher

\section{INTRODUCTION}

Marine snow aggregates have been intensively studied as to their role in transporting organic matter downward in the ocean. They are also interesting objects in their own right, forming special environments in which microorganisms thrive and interact with each other (Simon et al. 2002). Bacterial concentrations associated with aggregates usually exceed those in the surrounding waters, and measurements of microbial activity have shown that marine snow aggregates are microbial 'hotspots' (Azam 1998, Simon et al. 2002). The initial rates at which bacteria colonize an aggregate have time constants ranging from minutes to hours and can be predicted from water motion, aggregate size, bacterial motility, and probability of bacterial detachment (Fenchel 2001, Kiørboe et al. 2002). Chemotactic bacteria exhibit a biased 'random walk' in response to dissolved organics leaching from marine aggregates, resulting in elevated colonization rates (Berg 1993, 
Zimmer-Faust et al. 1996). Field and laboratory studies have largely focused on bacterial activity on and around marine snow aggregates, particularly the role of microbes in remineralizing marine snow material (Smith et al. 1992, Ploug \& Grossart 1999, Ploug 2001). However, marine snow aggregates are also colonized and utilized by other organisms whose activities affect the fate of the bacteria and aggregates (e.g. Kiørboe 2000, Simon et al. 2002).

Bacterial abundance on marine snow accounts for $<10 \%$ of the total bacteria in most pelagic environments, even in cases where aggregate concentration is high (reviewed in Simon et al. 2002). Predictions made using ambient bacterial concentration and rates of bacterial attachment and detachment are that the steady-state bacterial abundance on marine snow aggregates should scale as the aggregate size to the power of 1.45 ; however, field observations yield a scaling power factor of 0.25 (Kiørboe et al. 2002). The inference is that attached bacterial abundances are kept low by other factors, such as interspecific inhibition or grazing mortality.

Bacterial attachment and growth on aggregates transform the aggregates into favorable feeding grounds for bacterivorous flagellates, which can occur in and around marine snow aggregates at concentrations 10 to $10^{3}$ times more enriched than in ambient water (Caron et al. 1982, 1986, Artolozaga et al. 2000, Simon et al. 2002) and result in heavy protozoan grazing pressure on particle-attached bacteria (Güde 1979, Caron 1987). When grazing mortality is incorporated into models, the predicted steady-state bacterial abundances on aggregates agree well with observations (Kiørboe 2003), suggesting that attached bacterial abundance is indeed strongly regulated by grazing. Laboratory experiments have shown that grazing by protozoans could shift the composition of the marine snow bacterial community toward less diverse, more grazing-resistant strains (Jürgens \& Sala 2000, our unpubl. data). Despite this evidence for its importance, quantification of grazing mortality of marine snow bacteria is rare (Caron 1987, Lawrence \& Snyder 1998, Riemann et al. 2000, Artolozaga et al. 2002, Kiørboe et al. 2003, 2004).

We have previously investigated the individual physical and biological component processes in microcosms and have developed mathematical models to describe the short-term (minutes) and long-term (hours to days) dynamics of bacteria on aggregates (Kiørboe et al. 2002, Grossart et al. 2003b). Subsequent modelling and experimental studies have further characterized colonization of aggregates by protozoans and their grazing on attached bacteria (Kiørboe et al. 2003, 2004). In the present study, we investigated the various physical and biological component processes in meso- cosms. We measured both ambient particle size distributions and processes affecting bacterial populations, including abundances of free and attached bacteria, composition, growth rates, colonization rates, chemotaxis, and grazing mortalities. Our goal was to attain an integrated understanding of the dynamics of attached microbial communities in nature as governed by the component processes of particle formation, colonization, detachment, growth, and interspecific interactions between the microbes.

\section{MATERIALS AND METHODS}

Mesocosm. We set up 12 mesocosms in Isefjord, Denmark, at the Roskilde University field station 'Søminestationen' $\left(55^{\circ} 43^{\prime} \mathrm{N}, 11^{\circ} 46^{\prime} \mathrm{E}\right.$, average depth 5 to $7 \mathrm{~m}$ ) in conjunction with I. Dahllöf and M. Hjorth (DMU-Denmark). The study area is an isolated coastal water body with very restricted exchange with offshore water, and freshwater input is largely limited to rainfall. We operated 3 of the mesocosms (A, B and C) in parallel to provide replication for the experiments discussed herein. Each mesocosm was a cylinder formed of plastic sheeting, $1.25 \mathrm{~m}$ in diameter and $2 \mathrm{~m}$ deep, and with a volume of ca. $3 \mathrm{~m}^{3}$. Mesocosms were filled with water from the fjord on April 23, 2005 and suspended on a floating rig in the fjord. Turbulent mixing to keep particles suspended in each mesocosm was provided by an airlift system (Egge \& Heimdal 1994), as well as by natural wave action. The mesocosms were enriched with inorganic nutrients on April 23 and again in the late evening of April 29 to initiate a phytoplankton bloom. Inorganic nutrients were added as $144 \mathrm{mmol}$ ammonium $\left(\mathrm{NH}_{4} \mathrm{Cl}\right), 9 \mathrm{mmol}$ phosphate $\left(\mathrm{NaH}_{2} \mathrm{PO}_{4}\right)$ and $288 \mathrm{mmol}$ silicate $\left(\mathrm{Na}_{2} \mathrm{SiO}_{3}\right)$. Hydrographic properties, particle size distributions, and bacterial abundance, growth and production were monitored in all 3 mesocosms. Bacterial community composition and dynamics of particle-associated bacteria (colonization, grazing mortality, chemotaxis) were studied in detail for Mesocosm A, but less frequently for Mesocosms B and C. Depth-integrated water samples of 161 were collected from the 3 mesocosms for mesozooplankton species identification and enumeration. Dissolved nutrients and zooplankton samples were analyzed by standard techniques.

Particle distributions. We measured the concentrations and size distributions of suspended particles using an Elzone electronic particle counter for particles $<10^{-2} \mathrm{~cm}$ (95 and $240 \mu \mathrm{m}$ orifice tubes) and an in situ optical particle recorder for particles $>10^{-2} \mathrm{~cm}$. The optical particle recorder used a ca. $0.5 \mathrm{~cm}$ thick light sheet formed by a red laser optical system to illuminate suspended particles within a $10 \times 15 \mathrm{~cm}^{2}$ window. 
Particle images were captured by a digital camera (Nikon D70; 6 megapixels; 35mm lens) with a red bandpass filter. Typically, 200 pictures, corresponding to 151 of water, were taken and analyzed for particle size distributions using the software ImageJ (freeware by W. Rasband).

The size ranges detected by the 95 and the $240 \mu \mathrm{m}$ orifices partially overlapped, but there was a gap between the size ranges detected by the Elzone counter and the in situ recorder. We did not try to compensate for any differences in how the instruments assign diameter to a particle. We analyzed the 3 sets of measurements separately and then blended overlapping spectra together by using a tapered average when possible. Spectral values calculated with fewer than 4 particle counts per size range were discarded to avoid statistical bias. Data from particles smaller than $10^{-2} \mathrm{~cm}$ from the in situ recorder were removed to avoid the size region known to bias spectra for imaging instruments (Jackson et al. 1997). The number spectrum $n(d)$ at a given diameter $d$ (the average of the bin boundaries) was calculated by dividing the number of particles in a size range by the size range (upper lower boundary diameter) and by the sample volume. Volume spectra were calculated by multiplying $n(d)$ by the volume of a particle of that diameter, $V=\pi d^{3} / 6$.

Abundance of microorganisms. Bacterial abundance in each mesocosm was determined daily by direct cell count. 'Attached' bacteria were operationally defined as bacteria recovered from a size fraction of $>5 \mu \mathrm{m}$, and 'free' bacteria were defined as the size fraction from 0.2 to $5 \mu \mathrm{m}$. For each mesocosm, a $1 \mathrm{ml}$ aliquot was stained with SybrGreen I and filtered onto a $0.2 \mu \mathrm{m}$ filter to obtain the total number of bacteria. An additional $5 \mathrm{ml}$ aliquot was used to obtain the attached bacteria fraction on a $5 \mu \mathrm{m}$ filter. SybrGreen I-stained bacteria on the filters were counted by epifluorescence microscopy at 1000× magnification (Zeiss-Axioplan, Germany). At least 10 microscopic fields were counted, to yield a standard deviation of $<10 \%$. The difference between the 0.2 and the $5 \mu \mathrm{m}$ filters represented the free bacteria fraction. Protozoans were counted by simultaneously using light and epifluorescence microscopy (200 to $1000 \times$ magnification), depending on their abundance.

Bacterial diversity. Aliquots of $50 \mathrm{ml}$ water were collected daily from Mesocosm A and filtered sequentially onto a $5 \mu \mathrm{m}$ and then a $0.2 \mu \mathrm{m}$ polycarbonate membrane. The membranes were transferred to sterile Eppendorf tubes and preserved at $-20^{\circ} \mathrm{C}$ until DNA extraction. DNA of both free and attached bacteria was extracted following the protocol of Zhou et al. (1996), which includes treatment with zirconium beads and a mixture of $60^{\circ} \mathrm{C}$ hot phenol-chloroform-isoamylalcohol. DNA extraction was checked on an agarose gel $(1 \%)$. Amplification of 16S rRNA gene fragments and subse- quent DGGE analysis was performed according to Brinkhoff \& Muyzer (1997). Equal amounts of DNA were loaded in each lane (ca. $300 \mathrm{ng}$ ). DGGE gels were stained with SYBRGold (Molecular Probes) for $45 \mathrm{~min}$ and illuminated on a UV table (Biometra). Cluster analyses of the DGGE banding patterns were performed by the software GelCompare II, Version 3.5 (Applied Maths). The gels were internally standardized by selecting sequenced bands as standards. We applied 5 to $20 \%$ background subtraction depending on the signal-to-noise ratio of the corresponding gel. Patterns were compared by the curve-based approach using Pearson correlation and UPGMA (unweighted pairgroup method of analysis) to generate the dendrogram. We used the curve-based approach instead of comparing single bands because the former analysis is more robust (Ferrari \& Hollibaugh 1999).

Bacterial growth and production rates. Bacterial growth and production rates were estimated from thymidine (TdR) and leucine (leu) incorporation (Fuhrman \& Azam 1980, Simon \& Azam 1989). Separate sets of triplicate, $5 \mathrm{ml}$ samples with zero-time controls were incubated at in situ temperatures with $20 \mathrm{nM}{ }^{3} \mathrm{H}-\mathrm{leu}$ (specific activity $117 \mathrm{Ci} \mathrm{mmol}{ }^{-1}$ ) or ${ }^{3} \mathrm{H}-\mathrm{TdR}$ (specific activity $78 \mathrm{Ci} \mathrm{mmol}^{-1}$ ) for 0.5 to $1.5 \mathrm{~h}$. Zero-time controls and incubations were terminated by addition of $5 \%$ cold trichloroacetic acid (TCA). Samples were filtered onto $5 \mu \mathrm{m}$ pore size Nuclepore filters and the filtrate was collected and refiltered onto $0.2 \mu \mathrm{m}$ filters. This serial filtration yielded $>5 \mu \mathrm{m}$ (attached bacteria) and 0.2 to $5.0 \mu \mathrm{m}$ (free bacteria) size fractions. In most previous studies investigators size-fractionated their samples before adding the substrates (e.g. Karner \& Herndl 1992, Middelboe al. 1995, Smith et al. 1995, Riemann et al. 2000), whereas we size-fractionated our samples after the incubation with radioisotopes. We believe our method was less disruptive to the samples and more closely mimicked the natural conditions. Filters were rinsed 3 times with ice-cold 5\% TCA and once with ice-cold $80 \%$ ethanol. Filters were air-dried overnight and counted with Ultima Gold (PerkinElmer) scintillation cocktail.

Precursor incorporation rates were converted to bacterial production estimates using the factors $2 \times 10^{18}$ cells produced $\mathrm{mol}^{-1} \mathrm{TdR}$ incorporated and $1.5 \mathrm{~kg} \mathrm{C}$ produced $\mathrm{mol}^{-1}$ leu incorporated (Ducklow 2000). The same factors and assumptions were used for both size fractions. The carbon mass of newly divided (newly produced) cells was estimated from the ratio of the TdR and leu-based production rates (i.e. mol $\mathrm{Cl}^{-1} \mathrm{~h}^{-1}$ : cells $\mathrm{l}^{-1} \mathrm{~h}^{-1}$ ) (Simon \& Azam 1989). The mean coefficients of variation for TdR incorporation by free and attached bacteria fractions were 10 and $17 \%$, respectively. For leu incorporation they were 8 and 18\%, respectively. 
Bacterial colonization. Bacterial colonization behavior was investigated using model agar aggregates (Kiørboe et al. 2002). Aggregates of $\sim 4 \mathrm{~mm}$ diameter made of $2.5 \%$ agar (Cronenberg 1994) were suspended in $1 \mathrm{l}$ water collected from Mesocosm A daily. On alternate days the colonization experiment was repeated with water from Mesocosms B and C. Experimental incubations were conducted at near ambient water temperature in an environmental room. Triplicate aggregates were removed at $0,5,10,20,40,60$, 100 and $150 \mathrm{~min}$, and bacterial abundances on the aggregates were determined by DAPI-direct counts. A mathematical model was fit to the observations to deduce bacterial diffusivity $\left(D_{i} \mathrm{~cm}^{2} \mathrm{~s}^{-1}\right)$ and the rate of detachment minus growth $\left(\Delta_{;} \mathrm{s}^{-1}\right)$ (Kiørboe et al. 2002). $D$ determines the rate at which the bacteria encountered the aggregates based on a 'random-walk' motility pattern, whereas $\Delta$ determines the net loss of bacteria from the aggregates due to differences between detachment and growth. Note that the estimates of the 2 parameters are not independent of each other in the model. Initial and final samples of the ambient water for each experiment were also collected for enumerating ambient bacterial abundance and used to estimate ambient bacterial growth rates.

We examined bacterial chemotaxis by using agar aggregates enriched with marine broth $\left(\mathrm{MB} ; 15 \mathrm{~g} \mathrm{l}^{-1}\right)$ or glycine betaine $(\mathrm{GB}$; nominal concentration $1 \mathrm{mM})$ (Kiørboe et al. 2002). MB provides a broad spectrum of organic substrates for bacteria. GB is an abundant organic nitrogenous compound synthesized by marine phytoplankton and is a natural analog to dimethylsulfoniopropionate (DMSP), a climatically important organic compound (Charlson et al. 1987). Bacteria that use DMSP have been shown to take up and metabolize GB (Diaz et al. 1992, Kiene et al. 1998). Enriched agar aggregates were suspended in water from Mesocosm A on selected days in the same manner as for the other colonization rate experiments. Triplicate aggregates were subsampled through time, bacteria on the aggregates were enumerated by DAPI-direct counts, and a mathematical model was fit to the data to derive apparent diffusivity $\left(D^{*}\right)$ for the bacteria (Kiørboe et al. 2002). Elevated apparent diffusivity with enriched aggregates $\left(D^{*}\right)$ relative to non-enriched aggregates $(D)$ would indicate positive chemotaxis to the chemicals.

Grazing mortality of bacteria. Grazing mortality of attached bacteria was assessed by 2 approaches. In the first approach (Approach 1), glass slides were coated with $2.5 \%$ agar and pre-incubated in water from Mesocosm A for 16 to $20 \mathrm{~h}$ to establish an attached microbial community prior to experiments. The slides and the medium were then divided into 2 incubators: to one we added eukaryotic inhibitor to inhibit grazing by protozoans (200 $\mathrm{mg} \mathrm{l}^{-1}$ each of colchicine and cycloheximide;
Sherr et al. 1986, Hahn \& Höfle 1999); the other incubator was used as a control. Experimental incubations were conducted at near ambient water temperature. Slides were sampled from each incubator every hour for up to $12 \mathrm{~h}$ and stained with DAPI. Bacteria and protozoans on the agar surface were enumerated by epifluorescence microscopy. Protozoan grazing rates were estimated by fitting bacterial accumulation rates for the inhibitor treatment and the control to the model of Kiørboe et al. (2004). This experiment was conducted daily.

On selected days, grazing mortality was assessed with a multifactorial design (Approach 2). Water samples from the 3 mesocosms were mixed in equal portions. The resulting water was allocated to 4 treatments: untreated water, water plus inhibitor $\left(200 \mathrm{mg} \mathrm{l}^{-1}\right.$ each of colchicine and cycloheximide), water pre-screened through a $5 \mu \mathrm{m}$ filter, and pre-screened water plus inhibitor. Glass slides freshly coated with $2.5 \%$ agar were suspended in each incubator and sampled every 1 to $2 \mathrm{~h}$ for up to $18 \mathrm{~h}$; bacteria and protozoans on the slides were enumerated by DAPI direct cell counts. Differences in bacterial accumulation rate between the inhibitor treatment and the control indicate the effect of grazing mortality on bacterial colonization. Aliquots of the unscreened water (with and without inhibitors) were sampled at the beginning and at the end of the incubation for enumeration of ambient bacteria.

\section{RESULTS}

\section{Nutrient and plankton dynamics}

For the purpose of the discussion, we designate April 25 as Day 0 . Water temperature and salinity were fairly constant at 10 to $12^{\circ} \mathrm{C}$ and 20 , respectively, throughout the study. Nitrogen and phosphorus concentrations were lower than the nominal concentrations based on the amounts added (April 23), probably due to rapid draw-down of nutrients by the plankton, and the nutrient concentrations were rapidly reduced within $4 \mathrm{~d}$ (Table 1). The second nutrient addition (Day 4, April 29 evening) slowed the depletion of $\mathrm{N}$ and $\mathrm{P}$, but overall concentrations remained low. The dissolved P concentration was mostly $<0.3 \mu \mathrm{M}$, typical of oligotrophic water, and the N:P molar ratio of the dissolved nutrients was 40 to 400 , much higher than the Redfield ratio, suggesting that the system might have been P-limited. Silicate concentration dropped from $\sim 5$ to $<2 \mu \mathrm{M}$ during the study. Chlorophyll in all 3 mesocosms increased to a maximum of 16 to $21 \mu \mathrm{g} \mathrm{l}^{-1}$ on Day 1, then decreased rapidly thereafter (Table 1). The second addition of nutrients apparently slowed down the decline, but the chlorophyll concentration was $<5 \mu \mathrm{gl}^{-1}$ by the end of the study. Microscopy showed 
Table 1. Nutrient and chlorophyll (Chl) concentrations (mean $\pm \mathrm{SD} ; \mathrm{n}=3$ ) in Mesocosms $\mathrm{A}, \mathrm{B}$ and C. Dates of nutrient addition were April 23 and 29

\begin{tabular}{|c|c|c|c|c|c|c|c|}
\hline $\begin{array}{l}\text { Date } \\
(2005)\end{array}$ & Day & $\begin{array}{c}\mathrm{NO}_{2}^{-}+\mathrm{NO}_{3}^{-} \\
(\mu \mathrm{M})\end{array}$ & $\begin{array}{l}\mathrm{NH}_{4}^{+} \\
(\mu \mathrm{M})\end{array}$ & $\begin{array}{c}\mathrm{P} \\
(\mu \mathrm{M})\end{array}$ & $\begin{array}{c}\mathrm{Si} \\
(\mu \mathrm{M})\end{array}$ & $\mathrm{N}: \mathrm{P}$ & $\begin{array}{c}\text { Chl a } \\
\left(\mu \mathrm{g} \mathrm{l}^{-1}\right)\end{array}$ \\
\hline \multicolumn{8}{|l|}{ April } \\
\hline 23 & -2 & $18.69 \pm 0.73$ & $8.04 \pm 1.27$ & $0.62 \pm 0.12$ & $4.62 \pm 0.15$ & $44.4 \pm 8.5$ & \\
\hline 24 & -1 & $18.16 \pm 0.05$ & $1.58 \pm 0.75$ & $0.21 \pm 0.10$ & $3.97 \pm 1.61$ & $107.5 \pm 47.5$ & $14.99^{\mathrm{a}}$ \\
\hline 25 & 0 & $15.76 \pm 1.87$ & $1.76 \pm 1.14$ & $0.26 \pm 0.18$ & $5.34 \pm 0.82$ & $127.2 \pm 130.7$ & $17.09 \pm 3.01$ \\
\hline 26 & 1 & & & & & & $19.18 \pm 2.57$ \\
\hline 27 & 2 & $8.45 \pm 1.59$ & $0.25 \pm 0.02$ & $0.17 \pm 0.02$ & $2.87 \pm 0.20$ & $51.3 \pm 3.3$ & $14.79 \pm 4.24$ \\
\hline 28 & 3 & & & & & & $8.44 \pm 4.06$ \\
\hline 29 & 4 & $9.93 \pm 1.33$ & $0.90 \pm 0.45$ & $0.08 \pm 0.04$ & $2.48 \pm 0.20$ & $158.7 \pm 82.1$ & $6.66 \pm 3.51$ \\
\hline 30 & 5 & & & & & & \\
\hline \multicolumn{8}{|l|}{ May } \\
\hline 1 & 6 & $10.45 \pm 0.46$ & $2.71 \pm 0.51$ & $0.19 \pm 0.08$ & $2.53 \pm 0.26$ & $78.1 \pm 27.9$ & $5.79 \pm 3.35$ \\
\hline 2 & 7 & $7.73 \pm 3.01$ & $1.68 \pm 0.68$ & $0.07 \pm 0.07$ & $1.68 \pm 0.60$ & $176.5 \pm 119.4$ & $5.01 \pm 2.59$ \\
\hline 3 & 8 & & & & & & $2.67 \pm 1.86$ \\
\hline 4 & 9 & $7.86 \pm 0.46$ & $1.74 \pm 0.17$ & $0.05 \pm 0.02$ & $1.64 \pm 0.05$ & $235.7 \pm 145.8$ & $2.04 \pm 1.19$ \\
\hline
\end{tabular}

that the phytoplankton community was dominated by small flagellated cells, and diatom accumulation was not observed during the study.

Zooplankton were highly abundant in the mesocosms throughout the study (Table 2 ). Total zooplankton abundance averaged $2.2 \times 10^{5} \mathrm{~m}^{-3}$ between Days 0 and 7 with little variation, then decreased to $1.3 \times$ $10^{5} \mathrm{~m}^{-3}$ on Day 8 and remained steady for the rest of the study. In terms of numerical abundance, the zooplankton community was dominated by rotifers, which averaged $10^{5} \mathrm{~m}^{-3}$. The next most abundant groups were polychaete larvae and copepod nauplii, which each averaged $2 \times 10^{4} \mathrm{~m}^{-3}$. Acartia spp. and Centropages hamatus were the most abundant of the copepodites and adult copepods, averaging $10^{4} \mathrm{~m}^{-3}$. Other species were present in the range $10^{2}$ to $10^{3} \mathrm{~m}^{-3}$.

\section{Particle size spectra}

Particle volumes in all 3 mesocosms were dominated by large particles $(>100 \mu \mathrm{m})$ (Fig. 1). The particle volumes fluctuated in time but tended to decrease toward the end of the study. Integrating the area under each curve yields the total particle volume within a given size range. The integrated fractional volume of particles fluctuated more strongly in the medium size range than in the other 2 ranges (Fig. 1b). There was an overall decrease in particle volume in the large and medium size ranges (linear regression on log-transformed data; $\mathrm{p}<0.05)$, whereas the particle volume remained relatively constant in the small size range $(p>0.05)$. Because the particle size range sampled by the in situ recorder overlapped the zooplankton size
Table 2. Zooplankton abundance in Mesocosms A, B and C between Days 0 and 11

\begin{tabular}{|lrc|}
\hline \multirow{2}{*}{ Organism } & \multicolumn{2}{c|}{ Abundance $\left(\right.$ no. l $\left.^{-1}\right)$} \\
& Mean & SD \\
\hline Copepod nauplii & 21.1 & 9.0 \\
Oithona similis & 1.2 & 0.5 \\
Acartia spp. & 12.6 & 14.3 \\
Centropages hamatus & 11.2 & 9.6 \\
Pseudocalanus sp. & 0.8 & 0.4 \\
Temora longicornis & 0.6 & 0.5 \\
Other copepod species & 0.9 & 1.1 \\
Polychaete larvae & 24.8 & 19.7 \\
Other larvae & 1.9 & 1.0 \\
Rotifers & 106.3 & 90.3 \\
Others & 0.3 & 0.5 \\
\hline
\end{tabular}

range, some of the recorded large 'particles' could have been zooplankton. However, this seems to have been insignificant, since the temporal change in the volume spectrum of the large particles did not follow the temporal trend in zooplankton abundance.

\section{Bacterial abundance}

Total bacteria in all 3 mesocosms gradually increased in a similar fashion from Day 0 and leveled off by Day 4 (Fig. 2a). After the second addition of nutrients, total bacterial abundance showed a slight increase until Day 8, after which total bacteria remained relatively constant in Mesocosms B and $\mathrm{C}$, but decreased in Mesocosm A. The total bacterial abundance was in the range $5 \times 10^{5}$ to $15 \times 10^{5} \mathrm{ml}^{-1}$ throughout the 

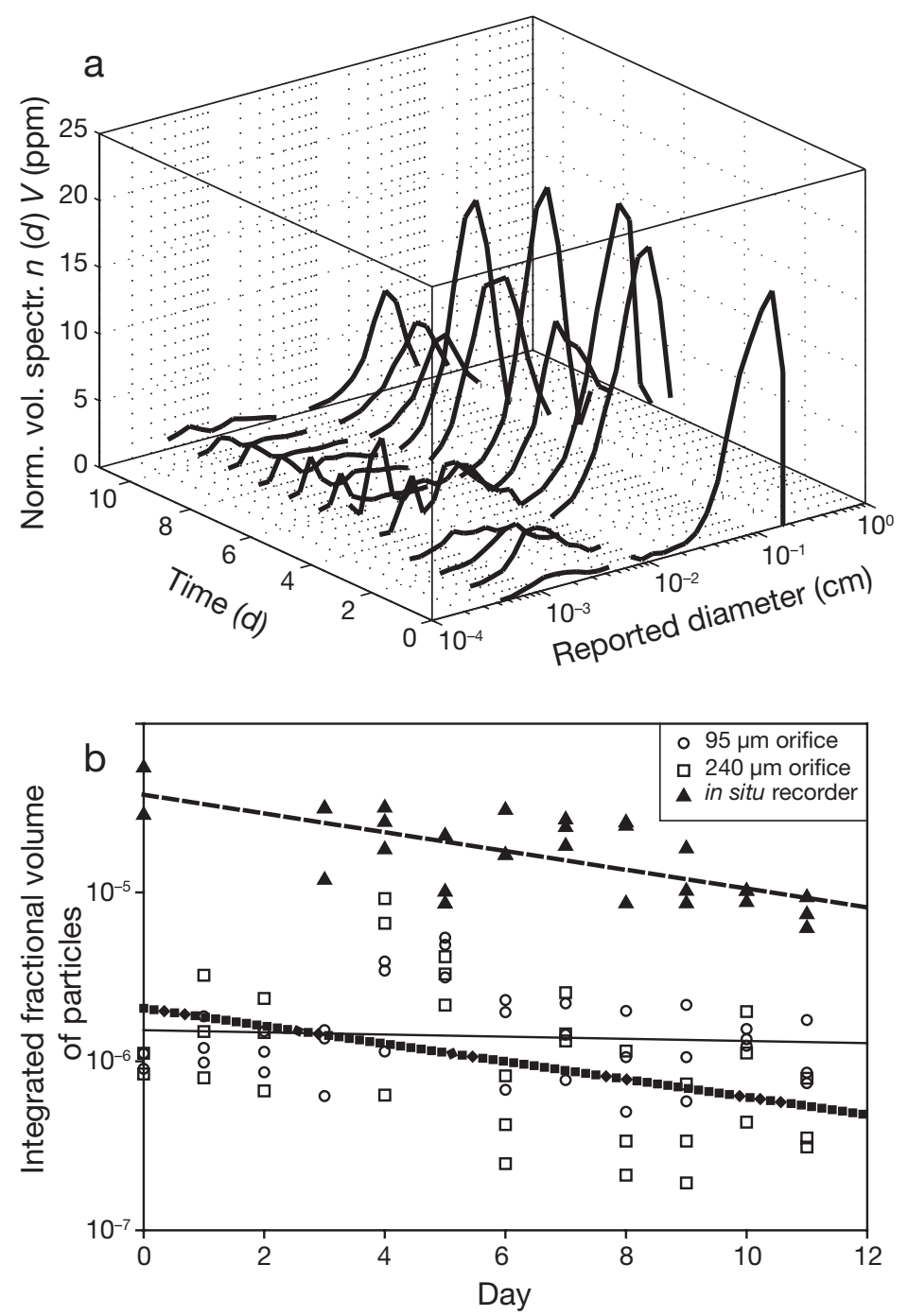

Fig. 1. Particle concentration in mesocosms. (a) Normalized particle volume spectrum (number spectrum $[n(d)] \times$ volume $[V])$ in Mesocosm A derived from measurements by Elzone particle counter (95 and $240 \mu \mathrm{m}$ orifice) and in situ particle recorder (combined data); Mesocosms B and C showed similar trends. (b) Integrated fractional particle volume in all mesocosms; note log scale on $y$-axis. Linear regressions for $240 \mu \mathrm{m}$ orifice and in situ recorder are significant $(\mathrm{p}<0.05)$

study. Attached bacteria increased by almost 2-fold between Days 1 and 3, then steadily decreased for the rest of the study (Fig. 2b). Overall, attached bacteria accounted for less than $25 \%$ of the total bacteria.

\section{Bacterial community composition}

DGGE fingerprints showed distinct banding patterns for free and attached bacteria (Fig. 3). Changes in species composition of free bacteria were relatively small since their DGGE banding patterns remained almost constant throughout the experiment. In contrast, diver- sity of the bacterial community on aggregates decreased as indicated by a declining number of bands during the experiment. Since the DNA yield for the attached bacterial community was low toward the end of the experiment mainly because of the very low number of aggregates present, we cannot exclude that PCR biases may have artificially lowered the number of DGGE bands.

\section{Bacterial growth and production}

TdR incorporation by total bacteria (free + attached) was largely consistent with the trend of total bacterial abundance. The incorporation rate increased initially from $\sim 2 \mathrm{pM} \mathrm{l}^{-1} \mathrm{~h}^{-1}$ to $10-12 \mathrm{pM} \mathrm{l}^{-1} \mathrm{~h}^{-1}$ within 4 to $5 \mathrm{~d}$
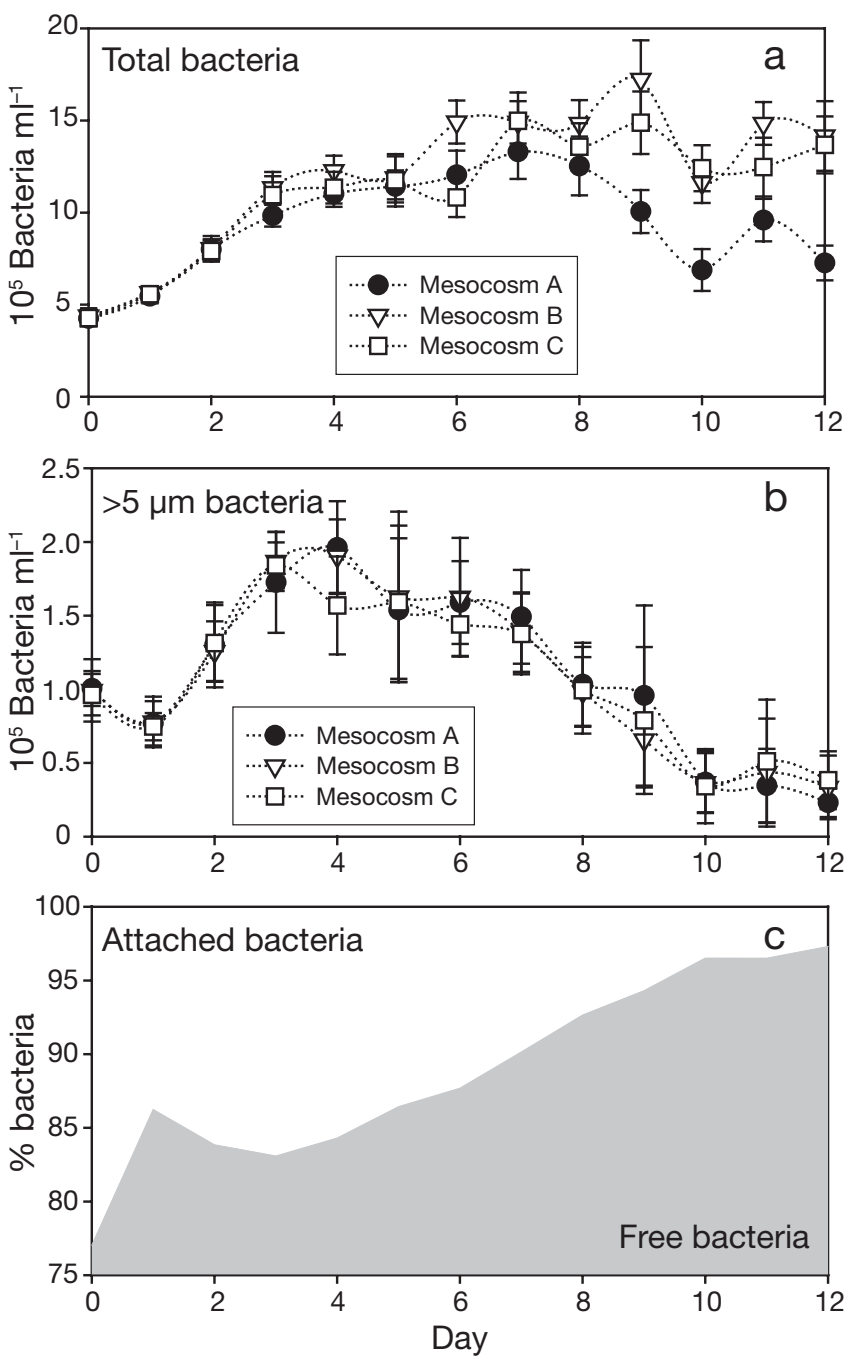

Fig. 2. Bacterial abundance in the mesocosms. (a) Total bacteria. (b) Abundance of attached bacteria defined as bacteria recovered from $>5 \mu \mathrm{m}$ fraction. (c) Relative abundance of free $(0.2$ to $5 \mu \mathrm{m})$ and attached $(>5 \mu \mathrm{m})$ bacteria in all mesocosms (combined data) 
and then fluctuated slightly for the rest of the study (Fig. 4). Leu incorporation overall followed a trend similar to that of TdR incorporation (Fig. 4). Attached bacteria accounted for, on average, 2 to $3 \%$ of the total activity. Cell production rates averaged $1.5 \times 10^{7}$ for free bacteria and $2.0 \times 10^{5}$ cells $\mathrm{l}^{-1} \mathrm{~h}^{-1}$ for attached bacteria. The estimated carbon content for newly produced attached bacteria averaged $7.8 \mathrm{fg} \mathrm{C} \mathrm{cell}^{-1}$, significantly larger than for free bacteria, which averaged $5.3 \mathrm{fg} \mathrm{C}$ cell $^{-1}$ (Student's $t$-test, $\left.\mathrm{p}<0.005\right)$. This estimation was consistent with microscopic observations that attached bacteria were often bigger than free bacteria. Cell production rates increased linearly with ambient bacterial abundances $(p<0.05$ for both free and attached bacteria); the specific growth rates estimated from the slopes of the regression lines for free and attached bacteria were 0.31 and $0.023 \mathrm{~d}^{-1}$, respectively (Fig. 5).

\section{Bacterial colonization}

Bacterial abundances on the model aggregates increased curvilinearly with time, as described previously (Kiørboe et al. 2002) (Fig. 6). The estimated diffusivity $(D)$ and rate of detachment minus growth $(\Delta)$ for Mesocosm A oscillated through time. Both $D$ and $\Delta$ increased after the second nutrient addition (late on Day 5) until Day 11, after which both parameters decreased again. The colonization experiments were repeated for Mesocosms B and C on selected days, and the estimated $D$ and $\Delta$ followed the same trend as for Mesocosm A (Fig. 6).

\section{Chemotaxis}

On all but $1 \mathrm{~d}$ of the chemotaxis experiments, the bacteria exhibited a positive response to $\mathrm{MB}$ and $\mathrm{GB}$, leading to higher colonization rates and higher apparent diffusivities $\left(D^{*}\right)$ relative to the control (non-enriched aggregates) (Table 3). The magnitude of chemotaxis, calculated as the ratio in diffusivities between the enrichment and the control, appeared to be strongest on Days 8 and 12, and weakest on Day 11 (Table 3). Paired $t$-tests on $D^{*}$ and $D$ showed an overall significant effect of the enrichment throughout the study ( $p=0.031$ for MB vs. control; $p=0.007$ for GB vs. control).

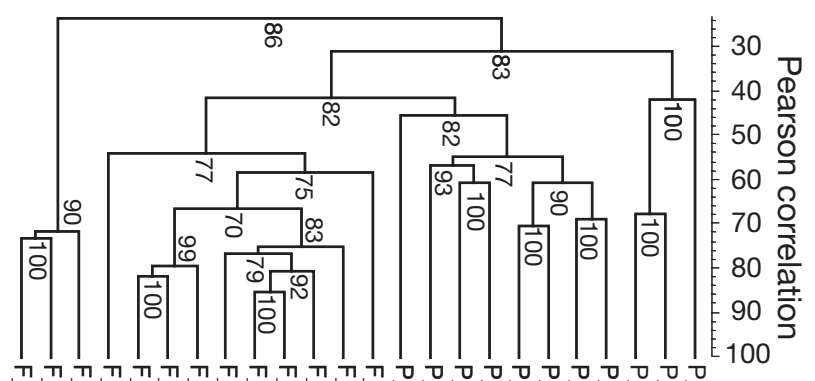

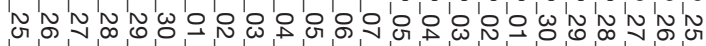

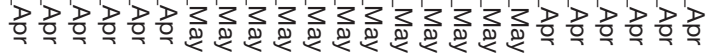

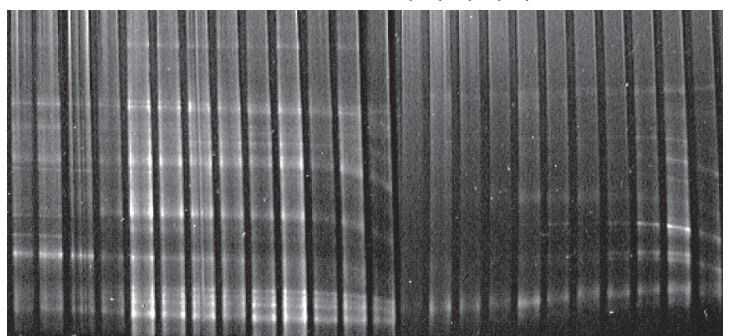

Fig. 3. Cluster analysis of DGGE banding pattern of free (F) and attached (P) bacteria using software GelCompare II, Version 3.5
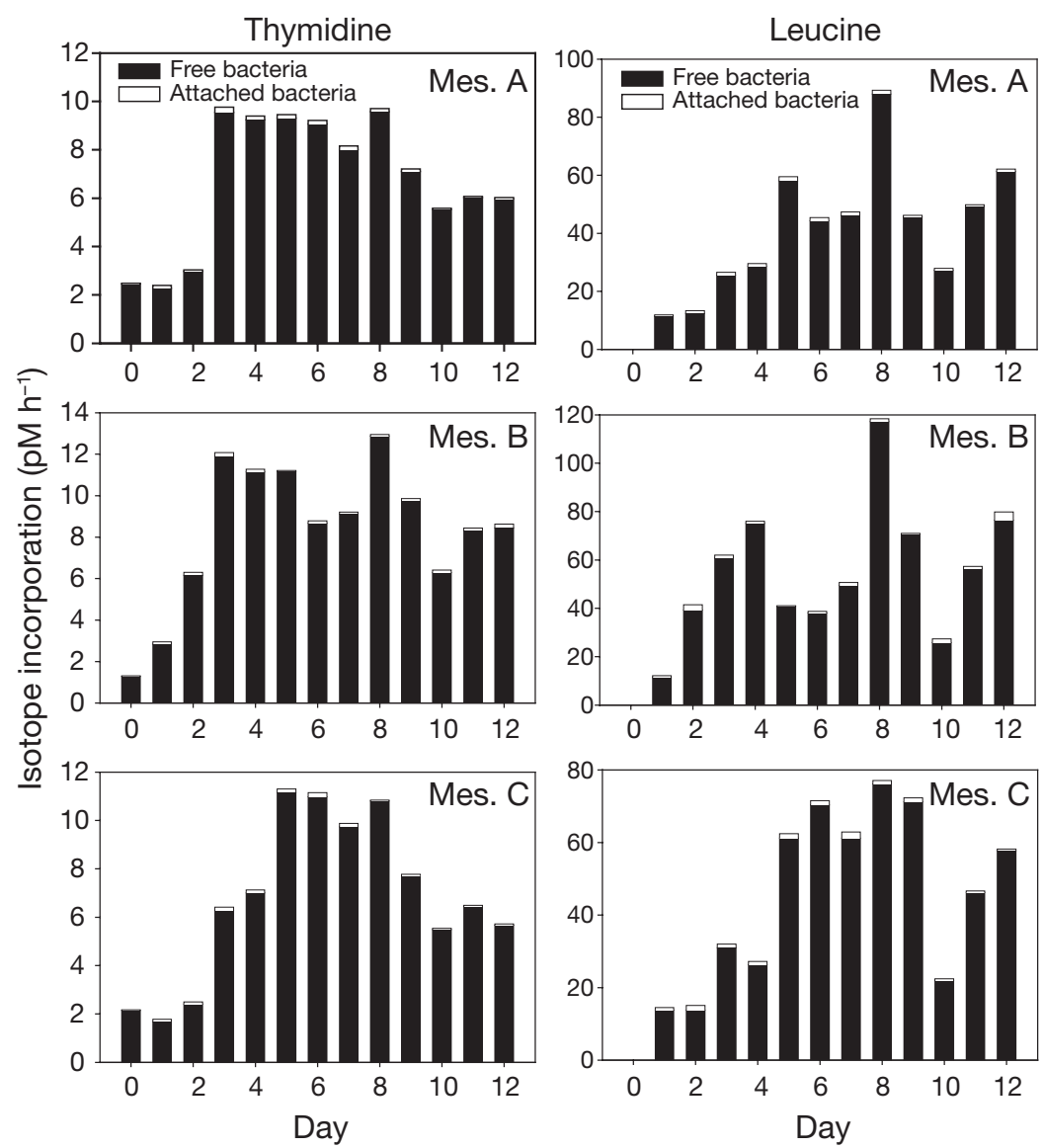

Fig. 4. Isotope incorporation by free $(0.2$ to $5 \mu \mathrm{m})$ and attached $(>5 \mu \mathrm{m})$ bacteria in Mesocosms A, B and C 

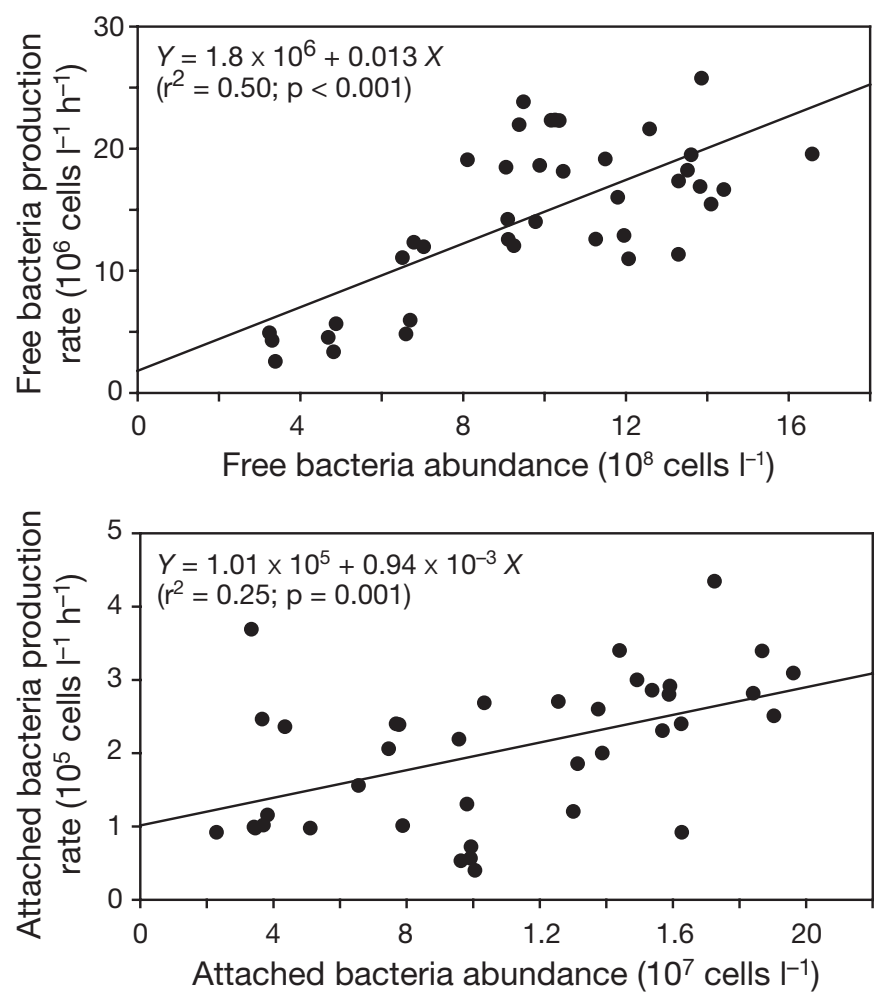

Fig. 5. Relationship between production rate and cell abundance for free and attached bacteria in all mesocosms (combined data). Linear regressions are fitted to the data

\section{Grazing mortality of bacteria}

Surprisingly few flagellates were attached to the slides after the pre-incubation (mean $32 \mathrm{~mm}^{-2}$, SD $17 \mathrm{~mm}^{-2}$ ). Bacterial abundance on the agar slides in the control during subsequent incubations was clearly reduced relative to the inhibitor treatment, suggesting that the ambient flagellate community was grazing on the surfaces without attaching (Fig. 7a). Estimated grazing mortality of the attached bacteria showed large fluctuations between Days 2 and 8 (range $=0.3$ to $>4 \mathrm{~d}^{-1}$ ) and decreased to near zero from Day 9 onward (Table 3 ).

For the multifactorial experiments (Approach 2) attached bacterial abundance remained low in the whole water incubation, but increased steadily in the inhibitor treatment (Fig. 7b,c). It increased almost identically with or without inhibitors in the prescreened water (Fig. 7c). Based on the temporal changes in attached bacterial abundance, grazing mortality was estimated to be 0.06 to $9.82 \mathrm{~d}^{-1}$ (Table 3 ). Grazing mortalities of free bacteria, derived from concurrent measurements of changes in ambient bacterial abundances, were $0.91 \mathrm{~d}^{-1}$ (Day 4), $0.22 \mathrm{~d}^{-1}$ (Day 6) and $0.06 \mathrm{~d}^{-1}$ (Day 10). In all cases we observed no or very few attached flagellates on slide surfaces $(0$ to $13 \mathrm{~mm}^{-2}$ ), although a fair number of heterotrophic fla-
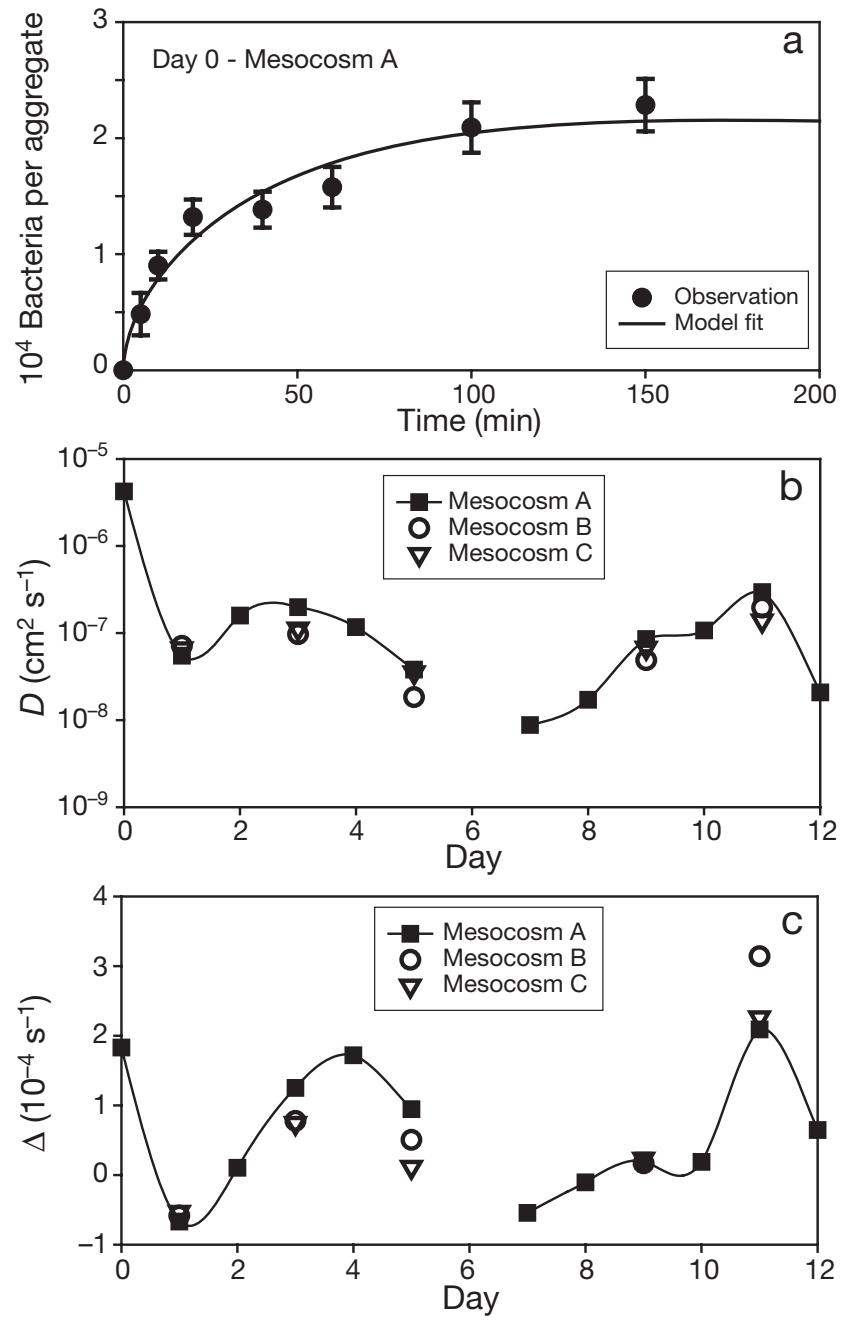

Fig. 6. Bacterial colonization experiments. (a) Typical results of colonization experiments $(n=3)$ : Mean \pm SE of bacteria per aggregate is shown. (b) Bacterial diffusivity derived from colonization experiments. (c) Delta (= detachment rate -

growth rate) derived from colonization experiments

gellates were present in the ambient water $\left(4 \times 10^{3}\right.$ to $12 \times 10^{3} \mathrm{ml}^{-1}$ ). When we incubated agar aggregates in the water for more than $2 \mathrm{~d}$ and observed them under a video-microscope, we noticed that many flagellates moved on the agar surface for a short time and then detached. Although we were not certain if these flagellates were bacterivorous, our observations do suggest that the flagellate community tended to attach themselves to surfaces for only a short period of time.

\section{DISCUSSION}

Contrary to our expectations, nutrient additions caused only a short transient phytoplankton bloom. The chlorophyll concentration increased moderately after the first nutrient addition but then quickly 
Table 3. Bacterial diffusivity and grazing mortality, showing bacterial diffusivities with $\left(D^{*}\right)$ or without $(D)$ chemotaxis in presence of marine broth (MB) or glycine betaine (GB) for Mesocosm A. $D^{*} / D$ represents enhancement of diffusivity due to chemotaxis. Grazing mortalities measured by Approach 1 and 2 are means \pm SE $(n=3)$. Residence time $(t)$ for attached bacteria in colonization experiments calculated as steady-state bacterial abundance on model aggregates divided by colonization rate. nd: no data (bacterial population did not reach steady-state during the experiment)

\begin{tabular}{|c|c|c|c|c|c|c|c|c|}
\hline \multirow[t]{2}{*}{ Day } & \multicolumn{3}{|c|}{ Diffusivity $\left(D\right.$ or $D^{*} ; \mathrm{cm}^{2} \mathrm{~s}^{-1}$ ) } & \multicolumn{2}{|c|}{$D^{*} / D$} & \multicolumn{2}{|c|}{ Grazing mortality $\left(\mathrm{d}^{-1}\right)$} & \multirow[t]{2}{*}{$t(\min )$} \\
\hline & Control & MB & GB & $\mathrm{MB}$ & GB & Approach 1 & Approach 2 & \\
\hline 0 & $4.23 \times 10^{-6}$ & & & & & & & \\
\hline 1 & $5.50 \times 10^{-8}$ & & & & & & & \\
\hline 2 & $1.59 \times 10^{-7}$ & $2.91 \times 10^{-7}$ & $2.44 \times 10^{-7}$ & 1.83 & 1.54 & $1.81 \pm 0.55$ & & 18.2 \\
\hline 3 & $1.98 \times 10^{-7}$ & & & & & $3.02 \pm 0.83$ & & \\
\hline 4 & $1.17 \times 10^{-7}$ & $1.86 \times 10^{-7}$ & $2.21 \times 10^{-7}$ & 1.59 & 1.89 & $0.78 \pm 0.29$ & $6.13 \pm 0.52$ & 13.6 \\
\hline 5 & $3.80 \times 10^{-8}$ & & & & & $4.59 \pm 0.58$ & & 16.1 \\
\hline 6 & & $2.36 \times 10^{-8}$ & $1.14 \times 10^{-8}$ & & & $4.45 \pm 1.56$ & $9.82 \pm 1.41$ & \\
\hline 7 & $8.79 \times 10^{-9}$ & & & & & $1.84 \pm 0.46$ & & nd \\
\hline 8 & $1.71 \times 10^{-8}$ & $6.81 \times 10^{-8}$ & $1.37 \times 10^{-7}$ & 3.98 & 8.01 & $0.32 \pm 0.27$ & & nd \\
\hline 9 & $8.52 \times 10^{-8}$ & $1.43 \times 10^{-7}$ & $1.85 \times 10^{-7}$ & 1.68 & 2.17 & $0.03 \pm 0.03$ & & nd \\
\hline 10 & $1.07 \times 10^{-7}$ & $2.42 \times 10^{-7}$ & $2.97 \times 10^{-7}$ & 2.26 & 2.77 & $0.00 \pm 0.10$ & $0.06 \pm 0.55$ & nd \\
\hline 11 & $2.95 \times 10^{-7}$ & $2.36 \times 10^{-7}$ & $2.72 \times 10^{-7}$ & 0.80 & 0.92 & $0.04 \pm 0.04$ & & 12.9 \\
\hline 12 & $2.08 \times 10^{-8}$ & $1.25 \times 10^{-7}$ & $1.22 \times 10^{-7}$ & 6.03 & 5.86 & $0.03 \pm 0.00$ & & 21.1 \\
\hline
\end{tabular}
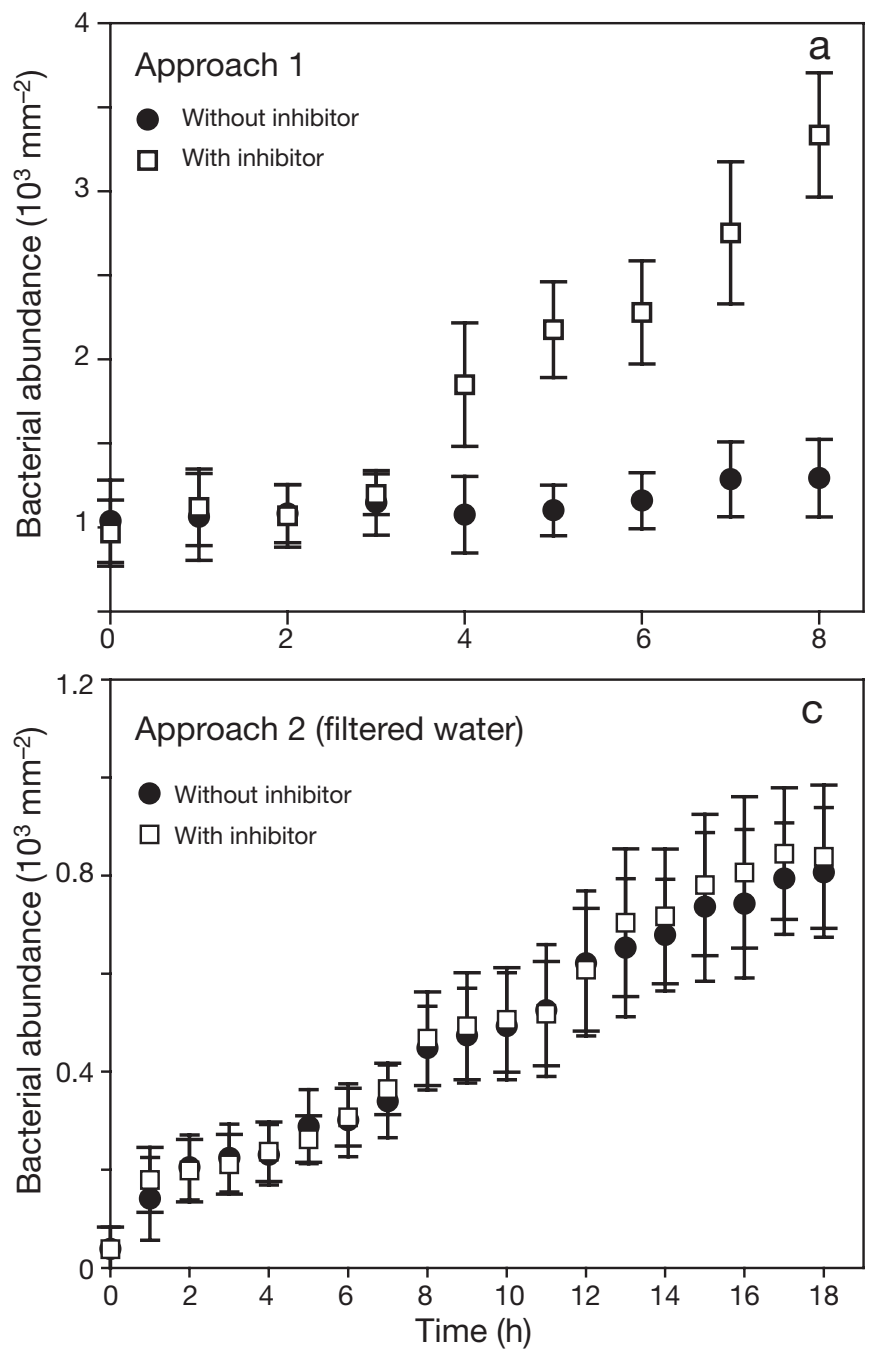

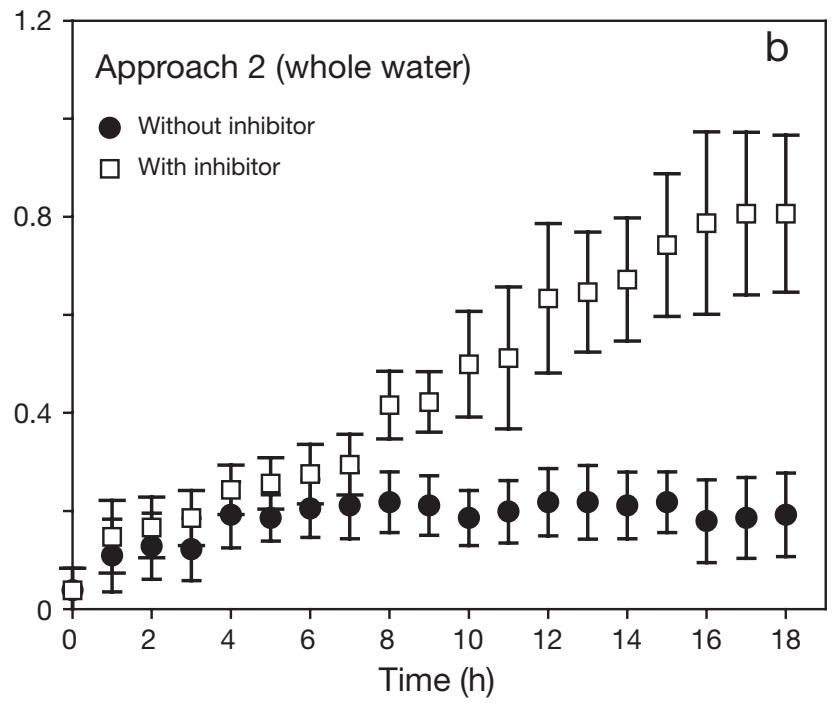

Fig. 7. Grazing experiments. (a) Typical results with Approach 1: agar slides precolonized by bacteria were incubated in mesocosm water with or without added eukaryotic inhibitors; slides were sampled through time for enumeration of surface-attached bacteria. $(b, c)$ Typical results with Approach 2: freshly prepared agar slides were incubated in whole or $5 \mu \mathrm{m}$ prefiltered mesocosm water with or without added eukaryotic inhibitors; slides were sampled through time for enumeration of surface-attached bacteria. Mean $\pm \mathrm{SD}, \mathrm{n}=3$ for all graphs 
declined. The high abundances of rotifers, polychaete larvae, copepod nauplii and omnivorous calanoid copepods in the mesocosms appeared to suppress an increase in phytoplankton biomass. However, added nutrients were drawn down almost instantaneously and particles up to $\sim 1 \mathrm{~mm}$ size were detected at the onset of the study. We calculated the critical particle volumetric concentration for the condition where phytoplankton growth and coagulation balance each other (Jackson 1990, 2005) as:

$$
C=\frac{\pi \mu}{8 \alpha \gamma}
$$

where $C$ is the fractional volume concentration of small phytoplankton, $\mu$ is the specific growth rate (assumed as $1 \mathrm{~d}^{-1}$ or $1.16 \times 10^{-5} \mathrm{~s}^{-1}$ ), $\gamma$ is shear rate (assumed as $1 \mathrm{~s}^{-1}$ ), and $\alpha$ is stickiness (assumed as 1). This yields a critical concentration of $4 \mathrm{ppm}$, close to that observed for the small particles. Although chlorophyll did not increase much during the experiments, ambient particle concentrations were potentially high enough for coagulation to be forming the larger particles. The fraction of attached bacteria paralleled particle abundance in the mesocosms. This temporal variation in the microbial community enabled us to investigate the effects of various physical and biological factors on the dynamics of the attached bacterial populations.

Attached bacteria abundance had a significant, albeit weak, correlation with the total ambient particle volume (Fig. 8). No significant correlations were found between particle volume and other parameters for attached bacteria, such as cell production rate, carbon production rate, specific growth rate and new cell mass. These results suggest that aggregates had negligible apparent effects on the physiology of attached bacteria, but provided additional substrata for bacter-

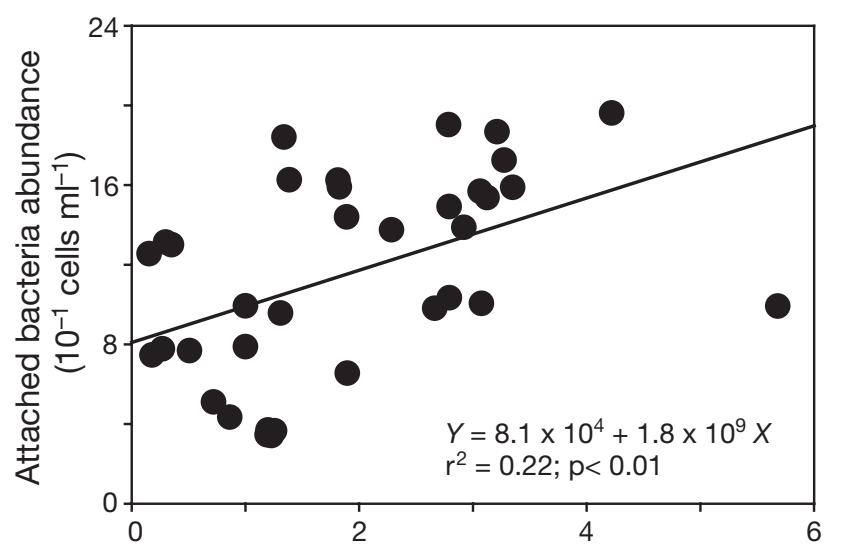

Combined integrated fractional volume of particles $\left(10^{-5}\right)$

Fig. 8. Relationship between attached bacteria abundance and integrated fractional particle volume. Linear regression is fitted to the data ial attachment. The estimated cell mass of attached bacteria was significantly higher than that of free bacteria, consistent with the DGGE results, and argues for different phylogenetic compositions of free and attached bacteria. Several studies have shown the presence of at least 3 functional groups of bacteria with respect to marine snow dynamics: free-living bacteria, particle-specialists, and generalists (Riemann et al. 2000, Kirchman 2002, Grossart et al. 2005). These functional groups differ not only in their particle-colonizing behavior, but also in their genetic composition (Grossart et al. 2006). Our present study showed that particle-associating bacteria were distinctly different from free bacteria genetically even in the absence of a sustained phytoplankton bloom or increased concentrations of organic aggregates.

Contrary to other studies (e.g. Smith et al. 1995, Ploug \& Grossart 2000, Grossart et al. 2003a,b), we did not find elevated rates of growth or carbon production of the attached bacteria. This difference may reflect the specific ecological and physiological conditions during our study or may be due to several methodological limitations associated with the isotope technique. (1) Since attached cells are in close contact with particle surfaces, the external isotope dilution factor may be higher than for free bacteria; (2) free bacteria could absorb the dissolved isotopes over their entire cell envelope whereas attached bacteria would have a relatively smaller surface area for absorption; (3) isotopes may be adsorbed onto particles and be unavailable for uptake by bacteria; (4) filtration of the samples through $5 \mu \mathrm{m}$ membranes may have led to a loss of bacteria which were loosely associated with particles; (5) attached bacteria are bigger and hence may have a higher internal pool of TdR and leu, than free bacteria, leading to a higher internal dilution factor, for which we did not correct. We did observe that the attached bacteria were significantly bigger than free bacteria; this may contribute to the problem of internal isotope dilution.

Alternatively, the lower than expected production rates for the attached bacteria in our study may have been due to the lack of sustained phytoplankton bloom in our mesocosms and to the fact that the ambient particles comprised a nutritionally poor environment for attached bacteria. Indeed, the specific growth rate of attached bacteria decreased rapidly as attached bacterial abundance increased, possibly reflecting resource limitation at the higher population density, whereas no comparable trend was found for the free bacteria (Fig. 9). The lack of correlation between particle volume and attached bacterial growth contrasts with results of previous studies which showed that attached bacteria tend to have higher growth rates and ectoenzyme activities. It should, however, be noted that 

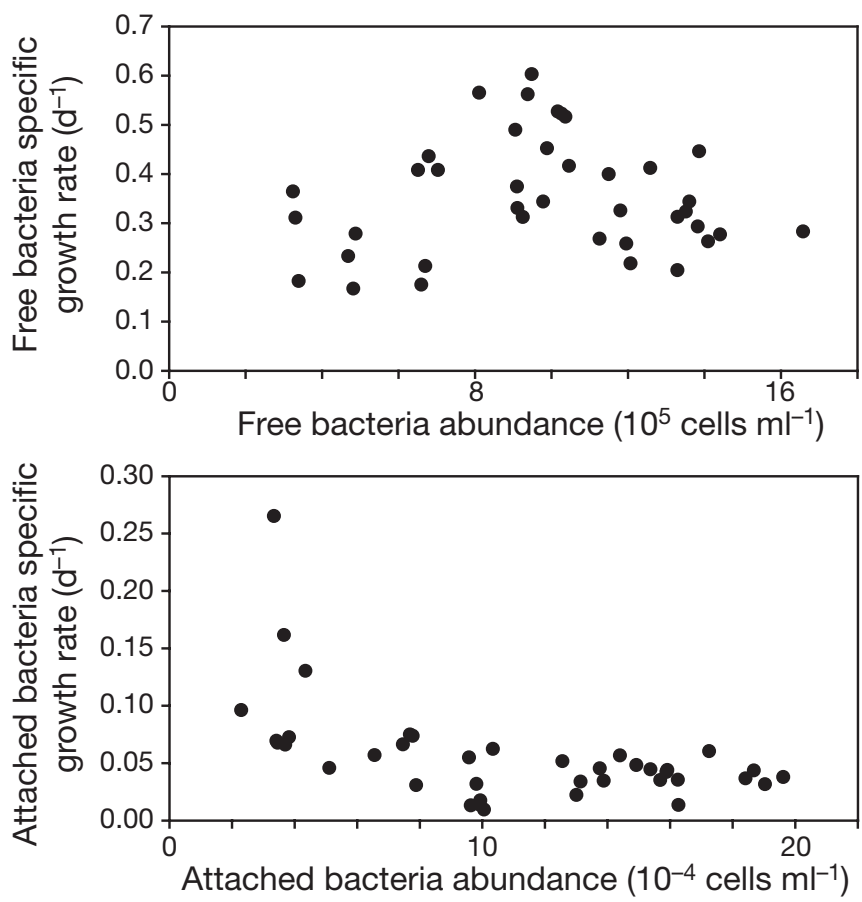

Fig. 9. Relationship between growth rate and cell abundance for free and attached bacteria in all mesocosms (combined data)

enhanced activity of attached bacteria is usually observed with diatom-derived marine snow (see e.g. Middelboe et al. 1995, Smith et al. 1995, Riemann et al. 2000). Because we did not have a diatom bloom and the phytoplankton were predominantly small flagellated species, our particles were unlikely to be diatomderived. The elevated growth and enzyme activities of attached bacteria commonly reported in the literature may be more specific to the marine snow constituents than a characteristic of attached bacteria in general. On the other hand, if bacteria attached to particles for a duration shorter than the incubation time, then the isotope incorporation by 'attached' bacteria could have been underestimated and that of free bacteria overestimated. We have some evidence for a short residence time of attached bacteria (see below).

Many marine bacteria are motile and their motility helps them to colonize particles (Fenchel 2001, Grossart et al. 2001). In our mesocoms, apparent bacterial diffusivities $(D)$ were 1 order of magnitude lower than previously reported diffusivities for pure cultures of marine snow bacteria (Kiørboe et al. 2002). This may reflect the fact that particle-specialists made up a very small fraction of the ambient population. The calculation of diffusivity assumed that all ambient bacteria had an equal tendency to colonize particles; however, the DGGE results showed a reduced number of bands for the attached bacteria population, and at the same time their abundance in the mesocoms also decreased.
The decreasing abundance of presumably increasingly specialized particle-colonizing bacteria could result in a low estimated diffusivity.

Another possible explanation for the low apparent diffusivities is that the tendency for bacterial attachment was reduced by strong grazing pressure near or at the surface. Past mesocosm studies on marine snow lacked information on grazing mortality of the bacteria (Simon et al. 2002). Our experiments consistently showed that grazing mortality was a strong top-down controlling factor for the attached bacterial populations. A comparison using all our data on attached bacterial abundance and grazing mortality shows that grazing mortality increased nonlinearly with increasing attached bacterial abundance, and suggests that grazing was strongly dependent on food resources, i.e. abundance of attached bacteria (Fig. 10). Grazing mortality was comparable to, or up to 2 orders of magnitude higher than, the growth rate of attached bacteria such that grazing could limit the accumulation of bacteria on aggregates due to growth. Using the data from the colonization experiments, we calculated the bacterial residence time $(t ; \mathrm{min})$ by dividing the steady-state bacterial abundance on model aggregates by the colonization rate. The calculated $t$, which represents the average time a bacterium stayed on the aggregate surface, was 21 min or less (Table 3). The short residence time implies that strong grazing pressure from flagellates rendered the aggregate surface an unfavorable environment for bacteria such that they detached or were consumed shortly after arrival. By comparison, grazing mortality of free bacteria was 1 order of magnitude lower, suggesting that the flagellates in the mesocosms were highly adapted to feeding on surfaces but not in free suspension, and that particle surfaces could be a very risky environment for attached bacteria (Caron 1987, Kiørboe et al. 2004). Interestingly the

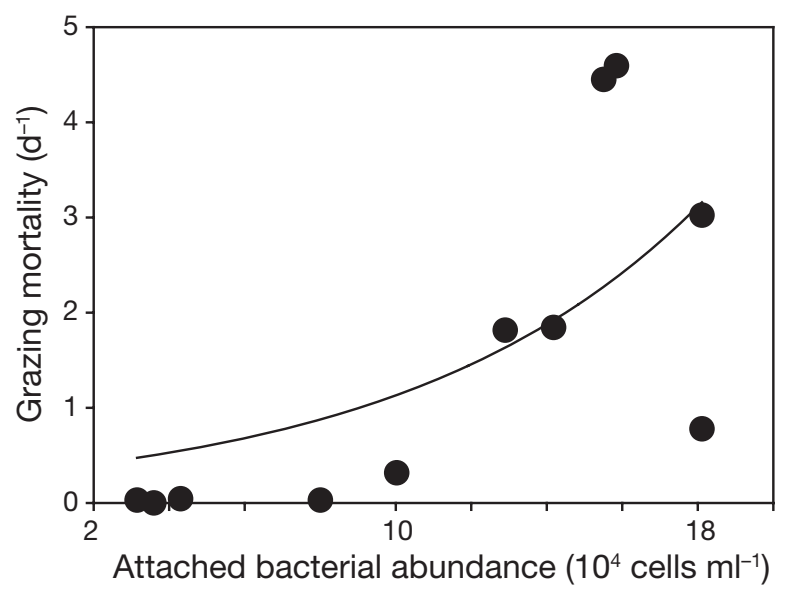

Fig. 10. Relationship between grazing mortality and abundance of attached bacteria. Trend line fitted by hand 
abundance of surface-attached flagellates remained low. Artolozaga et al. (2000) identified 3 types of protozoans: free-living protozoans in ambient water, protozoans that live inside marine snow aggregates, and protozoans that dwell in the aggregate-water interphase, where they establish a depleted microzone of $\sim 50 \mu \mathrm{m}$ around the aggregates. Artolozaga et al. (2000) observed that some protozoan species were found in large number almost exclusively in this interphase. Their presence near the aggregate surface may effectively control the attached bacterial population yet, without their attachment to the surface, their abundances may be easily underestimated.

Much of the world's surface ocean is characterized by low nutrient and primary production dominated by nondiatoms, yet the current understanding of marine snow and related microbial dynamics is biased toward eutrophic, diatom-bloom conditions. Our study has shown that microbial processes associated with particle dynamics in nutrient-limiting, non-bloom conditions may operate very differently. Under these conditions, grazing mortality appears to be the key (but often underappreciated) factor in regulating the colonization behavior of bacteria and their abundances on aggregates.

Acknowledgements. Financial support was provided by US NSF OCE-0352125 (K.W.T. and H.W.D.) and OCE-0352127 (G.A.J.), the College of William \& Mary Reves Graduate Student International Travel Grant (E.M.Y.), and the Danish Natural Science Research Council (T.K.). The authors thank I. Dahllöf, M. Hjorth (DMU-Denmark) and their research staff for the use of the mesocosm facility, and for providing the chlorophyll and nutrient data. Technical assistance from J. Melbye, M. K. Madsen, E. Pedersen, F. Knudsen and K. Hutalle is much appreciated. Contribution no. 2779 of the Virginia Institute of Marine Science.

\section{LITERATURE CITED}

Artolozaga I, Ayo B, Latatu A, Azua I, Unanue M, Iriberri J (2000) Spatial distribution of protists in the presence of macroaggregates in a marine system. FEMS Microbiol Ecol 33:191-196

Artolozaga I, Valcarcel M, Ayo B, Latatu A, Iriberri J (2002) Grazing rates of bacterivorous protists inhabiting diverse marine planktonic microenvironments. Limnol Oceanogr 47:142-150

Azam F (1998) Microbial control of oceanic carbon flux: the plot thickens. Science 280:694-696

Berg HC (1993) Random walks in biology. Princeton University Press, Princeton, NJ

Brinkhoff T, Muyzer G (1997) Increased species diversity and extended habitat range of sulfur-oxidizing Thiomicrospira spp. Appl Environ Microbiol 63:3789-3796

Caron DA (1987) Grazing of attached bacteria by heterotrophic microflagellates. Microb Ecol 13:203-218

Caron DA, Davis PG, Madin LP, Sieburth JMcN (1982) Heterotrophic bacteria and acterivorous protozoans in oceanic macroaggregates. Science 218:795-797

Caron DA, Davis PG, Madin LP, Sieburth JMcN (1986) Enrich- ment of microbial populations in macroaggregates (marine snow) from surface waters of the North Atlantic. J Mar Res 44:543-565

Charlson RJ, Lovelock JE, Andreae MO, Warren SG (1987) Oceanic phytoplankton, atmospheric sulphur, cloud albedo and climate. Nature 326:655-661

Cronenberg CHC (1994) Biochemical engineering on a microscale: biofilms investigated with needle-type glucose sensors. PhD dissertation, University of Amsterdam, Amsterdam

Diaz MR, Visscher PT, Taylor BF (1992) Metabolism of dimethyl-sulfoniopropionate and glycine betaine by a marine bacterium. FEMS Microbiol Lett 96:61-66

Ducklow HW (2000) Bacterioplankton production and biomass in the oceans. In: Kirchman DL (ed) Microbial ecology of the oceans. Wiley, New York, p 85-120

Egge JK, Heimdal BR (1994) Blooms of phytoplankton including Emiliania huxleyi (Haptophyta). Effects of nutrient supply in different N:P ratios. Sarsia 79:333-348

Fenchel T (2001) Eppur si muove: many water column bacteria are motile. Aquat Microb Ecol 24:197-201

Ferrari VC, Hollibaugh JT (1999) Distribution of microbial assemblages in the Central Arctic Ocean Basin studied by PCR/DGGE: analysis of a large data set. Hydrobiologia 401: $55-68$

Fuhrman JA, Azam F (1980) Bacterioplankton secondary production estimates for coastal waters of British Columbia, Antarctica, and California. Appl Environ Microbiol 39: 1085-1095

Grossart HP, Riemann L, Azam F (2001) Bacterial motility in the sea and its ecological implications. Aquat Microb Ecol 25: $247-258$

Grossart HP, Hietanen S, Ploug H (2003a) Microbial dynamics on diatom aggregates in Øresund, Denmark. Mar Ecol Prog Ser 249:69-78

Grossart HP, Kiørboe T, Tang K, Ploug H (2003b) Bacterial colonization of particles: growth and interactions. Appl Environ Microbiol 69:3500-3509

Grossart HP, Levold F, Allgaier M., Simon M., Brinkhoff T (2005) Marine diatom species harbour distinct bacterial communities. Environ Microbiol 7: 860-873

Grossart HP, Kiørboe T, Tang KW, Allgaier M, Yam EM, Ploug $H$ (2006) Interactions between marine snow and heterotrophic bacteria: aggregate formation and microbial dynamics. Aquat Microb Ecol 42:19-26

Güde H (1979) Grazing by protozoa as selection factor for activated sludge bacteria. Microb Ecol 5:225-237

Hahn MW, Höfle MG (1999) Flagellate predation on a bacterial model community: interplay of size-selective grazing, specific bacterial cell size, and bacterial community composition. Appl Environ Microbiol 65:4863-4872

Jackson GA (1990) A model of the formation of marine algal flocs by physical coagulation processes. Deep-Sea Res 37 : $1197-1211$

Jackson GA (2005) Coagulation theory and models of oceanic plankton. In: Droppo I, Leppard G, Liss S, Milligan $\mathrm{T}$ (eds) Flocculation in natural and engineered environmental systems. CRC Press, Boca Raton, FL, p 271-292

Jackson GA, Maffione R, Costello DK, Alldredge AL, Logan BE, Dam HG (1997) Particle size spectra between $1 \mathrm{~mm}$ and $1 \mathrm{~cm}$ at Monterey Bay determined using multiple instruments. Deep-Sea Res I 44:1739-1767

Jürgens K, Sala MM (2000) Predation-mediated shifts in size distribution of microbial biomass and activity during detritus decomposition. Oikos 91:29-40

Karner M, Herndl GJ (1992) Extracellular enzymatic activity 
and secondary production in free-living and marinesnow-associated bacteria. Mar Biol 113:341-347

Kiene RP, Hoffmann Williams LP, Walker JE (1998) Seawater microorganisms have a high affinity glycine betaine uptake system which also recognizes dimethylsulfoniopropionate. Aquat Microb Ecol 15:39-51

Kiørboe T (2000) Colonization of marine snow aggregates by invertebrate zooplankton: abundance, scaling and possible role. Limnol Oceanogr 45:479-484

Kiørboe T (2003) Marine snow microbial communities: scaling of abundances with aggregate size. Aquat Microb Ecol 33:67-75

Kiørboe T, Grossart HP, Ploug H, Tang K (2002) Mechanisms and rates of bacterial colonization of sinking aggregates. Appl Environ Microbiol 68:3996-4006

Kiørboe T, Tang K, Grossart HP, Ploug H (2003) Dynamics of microbial communities on marine snow aggregates: colonization, growth, detachment, and grazing mortality of attached bacteria. Appl Environ Microbiol 69:3036-3047

Kiørboe T, Grossart HP, Ploug H, Tang K, Auer B (2004) Particle-associated flagellates: swimming patterns, colonization rates, and grazing on attached bacteria. Aquat Microb Ecol 35:141-152

Kirchman DL (2002) The ecology of Cytophaga-Flavobacteria in aquatic enviornments. FEMS Microbiol Ecol 39:91-100

Lawrence JR, Snyder RA (1998) Feeding behaviour and grazing impacts of a Euplotes sp. on attached bacteria. Can J Microbiol 44:623-629

Middelboe M, Søndergaard M, Letarte Y, Borch NH (1995) Attached and free-living bacteria: production and polymer hydrolysis during a diatom bloom. Microb Ecol 29:231-248

Ploug H (2001) Small-scale oxygen fluxes and remineralization in sinking aggregates. Limnol Oceanogr 46:1624-1631

Editorial responsibility: Fereidoun Rassoulzadegan, (Contributing Editor), Villefranche-sur-Mer, France
Ploug H, Grossart HP (1999) Bacterial production and respiration in suspended aggregates -a matter of the incubation method. Aquat Microb Ecol 20:21-29

Ploug H, Grossart HP (2000) Bacterial growth and grazing on diatom aggregates: respiratory carbon turnover as a function of aggregate size and sinking velocity. Limnol Oceanogr 45:1467-1475

Riemann L, Steward GF, Azam F (2000) Dynamics of bacterial community composition and activity during a mesocosm diatom bloom. Appl Environ Microbiol 66:578-587

Sherr BF, Sherr EB, Andrew TL, Fallon RD, Newell SY (1986) Trophic interactions between heterotrophic Protozoa and bacterioplankton in estuarine water analysed using selective metabolic inhibitors. Mar Ecol Prog Ser 32:169-180

Simon M, Azam F (1989) Protein content and protein synthesis rates of planktonic marine bacteria. Mar Ecol Prog Ser 51:201-213

Simon M, Grossart HP, Schweitzer B, Ploug H (2002) Microbial ecology of organic aggregates in aquatic ecosystems. Aquat Microb Ecol 28:175-211

Smith DC, Simon M, Alldredge AL, Azam F (1992) Intense hydrolytic enzyme activity on marine aggregates and implications for rapid particle dissolution. Nature 359:139-142

Smith DC, Steward GF, Long RA, Azam F (1995) Bacterial mediation of carbon fluxes during a diatom bloom in a mesocosm. Deep-Sea Res II 42:75-97

Zhou J, Bruns MA, Tiedje JM (1996) DNA recovery from soils of diverse composition. Appl Environ Microbiol 62:695-724

Zimmer-Faust RK, de Souza MP, Yoch DC (1996) Bacterial chemotaxis and its potential role in marine dimethylsulfide production and biogeochemical sulfur cycling. Limnol Oceanogr 41:1330-1334

Submitted: November 18, 2005; Accepted: April 18, 2006 Proofs received from author(s): October 13, 2006 